REVIEW ARTICLE

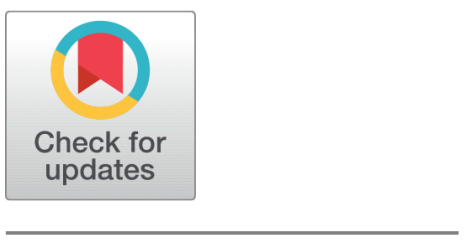

OPEN ACCESS

Received: 29.10 .2021

Accepted: 24.12 .2021

Published: 26.12 .2021

Citation: Rathee RK, Mishra SK (2021) Water Policies in India: A Critical Review. Indian Journal of Science and Technology 14(47): 3456-3466. https://doi.org/ 10.17485/IJST/v14i47.1828

* Corresponding author.

ravishrathee59@gmil.com

Funding: None

Competing Interests: None

Copyright: @ 2021 Rathee \& Mishra. This is an open access article distributed under the terms of the Creative Commons Attribution License, which permits unrestricted use, distribution, and reproduction in any medium, provided the original author and source are credited.

Published By Indian Society for Education and Environment (iSee)

ISSN

Print: 0974-6846

Electronic: 0974-5645

\section{Water Policies in India: A Critical Review}

\author{
Ravish K Rathee ${ }^{1 *}$, Sudipta K Mishra ${ }^{2}$ \\ 1 Assistant Professor, Civil Engineering Department, Maharishi Dayanand University, Rohtak- \\ 124001, Haryana, India \\ 2 Associate Professor, Civil Engineering Department, GD Goenka University, Gurugram- \\ 122103, Haryana, India
}

\section{Abstract}

Objectives: (a) Review the water institutional structures in India in the context of water demand and supply. (b) Review and critical analysis on the various water related policies in India. (c) To understand the challenges and opportunities in water sector in India and to provide recommendations and guidelines for achieving them. Methods: Various water policies have been evolved and amended since 1987 by the Government of India and other policymakers, describing the factual scenarios of the water resources and their administrations too. This paper strives to critically review these water policies and provide recommendations in view of present challenges and opportunities of water sector. Findings: Addressing the impact of climate change on water availability and economy, concluded that the water imbalance is due to poor management from various levels of states, industries, surface runoff, lack of floodwater management, lack of dams, lakes, river basins and many more. The focus should be on river water management and building dams for water conservation. The government should frame more policies that can be strictly followed by the industries and other wastewater management agencies to make our future secure with preserved water resources. Novelty: To overcome the above challenges/ gaps in the previous water policies in India, the Author, here find its objective through this paper to review the evolution of various water policies implicated in India briefly focusing on the increasing demand for water by the escalating population, its past and present institutional arrangements and conservation practices including reusing wastewater after proper treatment.

Keywords: Development; Government of India; Hydrology; Resource Management; Water Policy

\section{INTRODUCTION}

\subsection{Context}

Out of many resources over the earth, water is the most essential resource for all living beings. Only $2.5 \%$ of the total water present on the planet is fresh water and almost 
$68.7 \%{ }^{(1)}$ of this fresh water is available in the structure of ice caps and glaciers. In addition, out of the staying $31.3 \%$ water, $1.2 \%$ is available in remote, distant regions and accessible just as regular precipitation in monsoonal floods, which can't be utilized without any problem. So only $30.1 \%$ of the freshwater available on earth or only about the $0.75 \%$ of the total water present over the earth is traceable by men. As time passes, water resources have been exhausting and clean drinking water is less accessible to support humanity. At present pretty much $0.08 \%$ of the world's water ${ }^{(2)}$ is manhandled by humankind in reliably developing energy for sterilization, drinking, accumulating, loosening up, and agribusiness. Water is very essential element for survival, existence, and growth and is used by all the living organisms on earth.

This small percentage of potable water and the fast-growing population has put great stress on our natural resources at various locations throughout the world. So, to minimize stress over our natural resources, efforts have been made by several government agencies for water resource management by incorporating its $1^{\text {st }}$ national water policy in 1987 and further its amendments time and again, as when required, which focus on its optimum use and lessens the burden on the environmental assets. "Water Resource Management" is the activity of organizing, creating, appropriating, and dealing with the standout use of aquatic resources. It is also a piece of water cycle executives. Probably the pronounced worry is for our water resources and their sustainability for future. Due to the rising water demand, it is foremost important to conserve it.

\subsection{Review of Water Policies globally}

As and when the stresses are realized over the water resources, every time new initiative have been taken for proper utilization, management, and conservation of the natural resources. Escribano ${ }^{(3)}$ studied the policy changing the climate and the water resources in the states of European Union and Spain and gave water management regulations. Rouillard ${ }^{(4)}$ evaluated the execution of the IWRM process for improving the water regulations in Bangladesh. Kampragou ${ }^{(5)}$ proposed a fundamental change from the draught disaster to risk management, heeling the policy gaps in the European Union. Yoshihide ${ }^{(6)}$ signified the human water consumption augmented the hydrological drought over the World. Brown ${ }^{(7)}$ research gave a scientific skeleton of sustainable water management. Walmsley ${ }^{(8)}$ also gave a strategic approach for sustainable water resources for irrigation and water systems with the implementation of Integrated Water Resource Management (IWRM) theory. Tingey ${ }^{(9)}$ incorporated on-field water storage wellbeing into watershed strategy structures, which was known to be world's best practice strategy for private dam security responsibility and affirmation. Shen ${ }^{(10)}$ found that absence of required administrative measures, ineffectual arrangement execution, and deficient oversight and control are the primary hindrances to wipe out the on-going Illegal, Unregulated and Unreported (IUU) issue in Distant Water Fisheries (DWF).

\section{- Review of Water Policies at National level}

For switching the standard methodology of future projection interest and achieving an inventory side reaction to fulfill that need, we should begin the scenario with a view of the limited water accessibility and start figuring out the best way to deal with our water requirements. Iyer ${ }^{(11)}$ said that to have a more evenhanded and comprehensive water assets, the executives, supremacy needs to move from huge incorporated, capital-serious "Water Resource Development" (WRD) projects with large dams and repositories and waterway frameworks. The decentralized and local area drove, water-gathering and watershed-improvement programs, with the huge tasks being viewed as ventures of the last resort; and the over exploitation of groundwater should be seriously limited in light of a legitimate concern for asset protection and also for equity. Pol ${ }^{(12)}$ stated that the strategy needs to fuse at all-encompassing steps, the standards of lucidity, liability, and parting for all dynamic in water sector. Another perspective that would require our consideration, identifies with being in the overall jobs of the state and the local area for example from 'prominent area' or sovereign forces of the state to the state as trustee holding regular assets in broad daylight trust for the local area ${ }^{(13)}$. As of now, the greater part of the issues that exist in the Indian water area are identified with water transfer, compromise, monetary and financial strategies, coordinated water resources management, responsibility, decentralization, and speculation ${ }^{(14)}$. Further, Shah ${ }^{(15)}$, focused on the Collective efforts by the varsity, NGOs, think tanks, private \& Govt. organizations and water rights, biological equity \& water demands, also accentuation on water asset \& watershed management.

\subsection{Research Gaps and Research Objectives}

1.3.1 Central Government formulated the National Water Policy in 1987, which was accordingly audited and overhauled in the years 2002 and 2012. Since the reception of the National Water Policy 2012, many difficulties including water shortage have arisen fundamentally in the water sector. Revision of National Water Policy 2012 has been envisaged to address the present challenges (as indicated below) in the water sector:

- After several updating in the past decades, still there are great deals of changes as per the current scenarios and the prioritization of the water utilization. 
- Diminishing spring sets in Himalaya Region.

- Drying of rivers and rivulets due to negligence in their betterment/ regulations.

- Lack of various latest technologies and systems like RS, GIS and satellite imageries etc. in ancient water policy formulations and mapping with ground realities.

- Command area development needs to be done for constructing small irrigation channels to benefit farmers.

- Unbalanced and inefficient water supply in various sectors like Village water supply, urban areas and in agriculture areas etc.

- Human caused challenges like river/ water pollution, degrading water quality, bad design of drainages, acts against the natural climate/ environment etc.

\subsubsection{To overcome the above challenges/gaps in the previous water policies in India, the Author, here find its} objective through this paper to review the evolution of various water policies implicated in India briefly focusing on the increasing demand for water by the escalating population, its past and present institutional arrangements and conservation practices including reusing wastewater after proper treatment. The objectives of this paper are:

- Review the water institutional structures in India in the context of water demand and supply.

- Review and critically analysis on the various water related policies in India.

- To understand the challenges and opportunities in water sector in India and to provide some recommendations and guidelines for achieving them.

The authors have made efforts to explain the above-mentioned objectives by dividing the whole paper into basically three research objectives sections. These three Research Objectives are further categorized into various subsections as explained below.

\section{Research Objective I}

\subsection{Variation of water supply and demand}

India's water accessibility: With the expanding population of India along with the overall development, the usage of water is expanding drastically. On an average under normal conditions, India gets yearly precipitation (counting snowfall) of around $4000 \mathrm{~km}^{3}$. Notwithstanding, there occurs huge spatial and temporal variations in appropriation of precipitation and consequently the accessibility of water in reality throughout the nation. It is assessed that out of the $4000 \mathrm{~km}^{3}$ water, $1868 \mathrm{~km}^{3}$ is expected to stream in waterways annually. Out of this absolute accessible water asset, just $1121 \mathrm{~km}^{3}$ is utilizable $\left(689 \mathrm{~km}^{3}\right.$ from surface water assets and $432 \mathrm{~km}^{3}$ from groundwater assets). Whereas water demand in the year 2000 was $633 \mathrm{~km}^{3}$ and it is probably going to be $1095 \mathrm{~km}^{3}$ by 2025. Due to the quick ascent in population and developing economy of the country, there will be a ceaseless expansion in demand for water, and it will turn out to be scant in the coming many years.

Figure 1 shows the demographic data and stats to show the variation of supply and demand of water in India. Chowdhary ${ }^{(18)}$ in his study found that, while framing water/ management strategies at Local Bodies level, various specific people parting the Local Body meetings either directly or indirectly are benefitted while the others/ weaker sections are deprived off these infrastructure facilities.

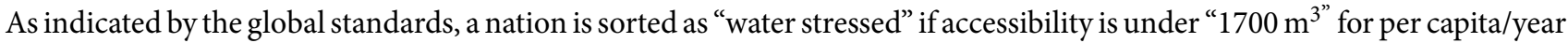
and delegated as "water scarce" if it is under " $1000 \mathrm{~m}^{3}$ per capita per year". In India, this accessibility of surface water during the years 1991 and 2001 were $2309 \mathrm{~m}^{3}$ and $1902 \mathrm{~m}^{3}$ respectively. The per person surface water accessibility has been forecasted to be diminished to $1401 \mathrm{~m}^{3}$ and $1191 \mathrm{~m}^{3}$ respectively the year 2025 and 2050. Per person water accessibility during 2010 was $1589 \mathrm{~m}^{3}$ against $5200 \mathrm{~m}^{3}$ in the year 1951 in the country.

\subsection{Existing Institutional Water framework/ infrastructure in India}

There are some water resource management policies framed at the International and National levels which are focused on water conservation and its proper use. It is very important to frame water management policies as water is the most essential molecule for every living body for its survival. It has been observed that mainly in the developed and developing countries the lifestyle of the people have changed a lot like traveling by personnel vehicles instead of public vehicles, living in isolated families instead of combined ones, growing more and more industries and decreasing agriculture land and hence increasing stress to our present available infrastructure facilities leading to rapid deforestation, urbanization, industrialization which is further leading us away from the nature. 


\section{INDIA's Water Wealth}

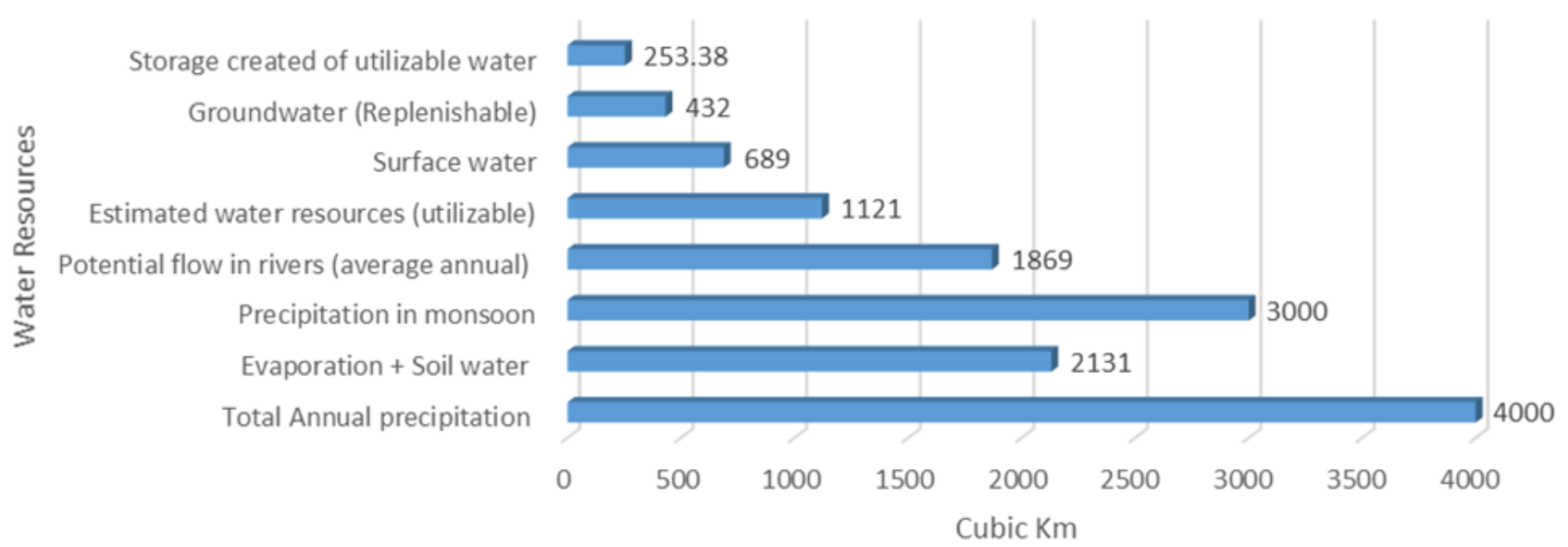

Fig 1. Demographic, Water accessibility, supply and demand- India (Source: ${ }^{*}$ Water Scarcity Clock $^{(16)}$; India’s water wealth ${ }^{(17)}$ )

Now, the consequences of disturbing nature and the natural phenomenon of the various environmental cycles can be easily observed in the form of fast depleting of the ozone layer, fast melting of glacier's ice, uneven rains throughout the year leading to draughts in some areas, and floods in the other ones. Water, being a plentiful normal asset, is turning into a more important aspect because of dry spells occurring in many of the places of the planet ${ }^{(19)}$. Moreover, the drought-prone areas are more dependent on the groundwater, which are being exploited more and resulting in barren lands. However, in case of flood-prone areas, the situation occurs due to extensive water logging leading the soils saline and ultimately affecting the soil fertility with decreased agriculture production.

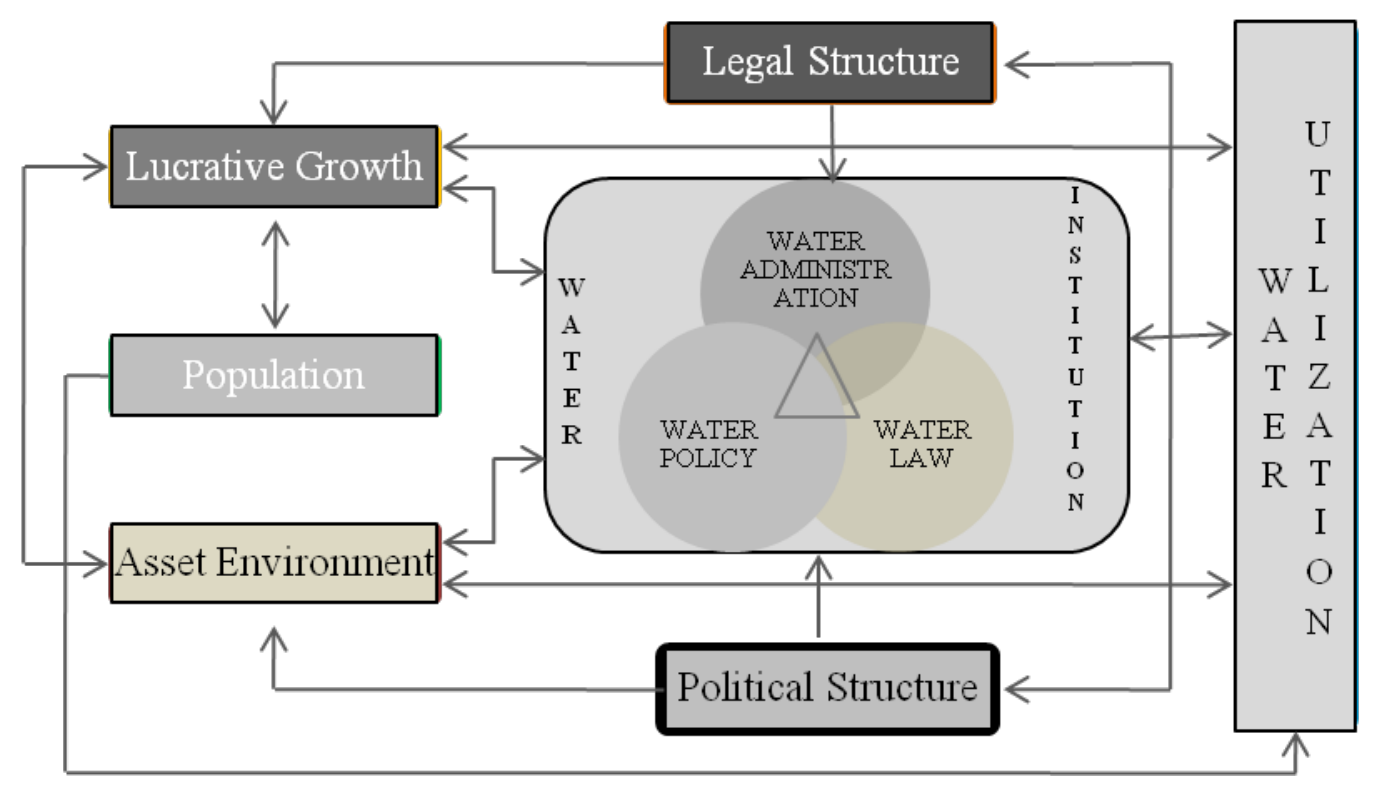

Fig 2. Institutional framework/ water framework in India (Source: Saleth and Dinar ${ }^{(20)}$ )

Broad hydrological data is important to create water assets and secure them. Water Management is critical, since it decides future water demands and further water distribution equitably and judicially. All these Water-related issues can be tackled under set policies and regulations at international, National, State, and district levels by the competent authorities and their 
implications too. Kathpalia ${ }^{(21)}$ proposed a new institutional framework focusing on the integrated planning for groundwater and surface water including conservation, recycling, and reutilizing the water. Another proposal was to constitute the National Water Resource Council as the highest policy-making agency headed by the Prime Minister and the Chief Ministers of each state being the members of the council.

\subsection{Need for water management/ Policy to minimize the demand-supply gap}

Water is the very essential element for survival, existence, and growth is used by all the living organisms on earth. In India, the population is growing in a very remarkable front. If we see the statistics of the total population, decadal growth, and density of population (as given in Table 1), the effects of population growth and the increasing density of population are indicating a big warning siren of diminishing our natural resources, and water being one of them. Suresh ${ }^{(22)}$ in his study compared the water availability and demand between the various water sectors and also forecasted water availability and user's demand in 2025 and 2050. Mukherji ${ }^{(23)}$ in her paper described the depleting ground water related issues and correlated it with the recent trends in its "water-energy-food-nexus".

Ideally, water resource is the board orchestrating has to regard to all the fighting solicitations for water and attempts to dispense water on an impartial reason to satisfy all uses and demands. There should be a proper balance for water usage among humans and the environment. To maintain this balance certain water policies at the national, state, or sub-state levels are of utmost necessity.

Table 1. Total population, decadal growth, and density ${ }^{(24)}$

\begin{tabular}{llll}
\hline Census year & Total population (in Crores) & Decadal growth & Density (per Sq. Km) \\
\hline 1941 & 31.87 & 14.2 & 96.95 \\
1951 & 36.11 & 13.3 & 109.85 \\
1961 & 43.92 & 21.6 & 133.60 \\
1971 & 54.82 & 24.8 & 166.76 \\
1981 & 68.33 & 24.7 & 207.86 \\
1991 & 84.64 & 23.9 & 257.48 \\
2001 & 102.87 & 21.5 & 312.94 \\
2011 & 121.02 & 17.6 & 368.15 \\
2020 & 138.00 & - & 464.15 \\
\hline
\end{tabular}

\section{Research Objective II}

\subsection{Basic Principles of Water Policies:}

The basic principles over which, these policies were governed so that there are some shared approaches in managing, developing, and executing water resources are as follows:

1. (a) Planning, advancement, and the executives of water assets are represented by national points of view on an incorporated and ecologically stable premise, keeping the personal, social and monetary requirements.

(b) Reuse and redistribution of water.

(c) Water network taken for food security, fair and feasible improvement in everyone's living standard.

(d) Water use ought to be viewed as a privilege to life's basic need throughout everyday life. All things considered, water ought to have a precautionary need over every single user.

(e) Water is basic for food of eco-framework, and subsequently, natural necessities ought to be given due thought.

(f) Water quantity and quality both are associated and ought to be managed in a consolidated way with more broad environmental organization approaches including the use of monetary inspirations and disciplines to decrease squander and its contamination. 


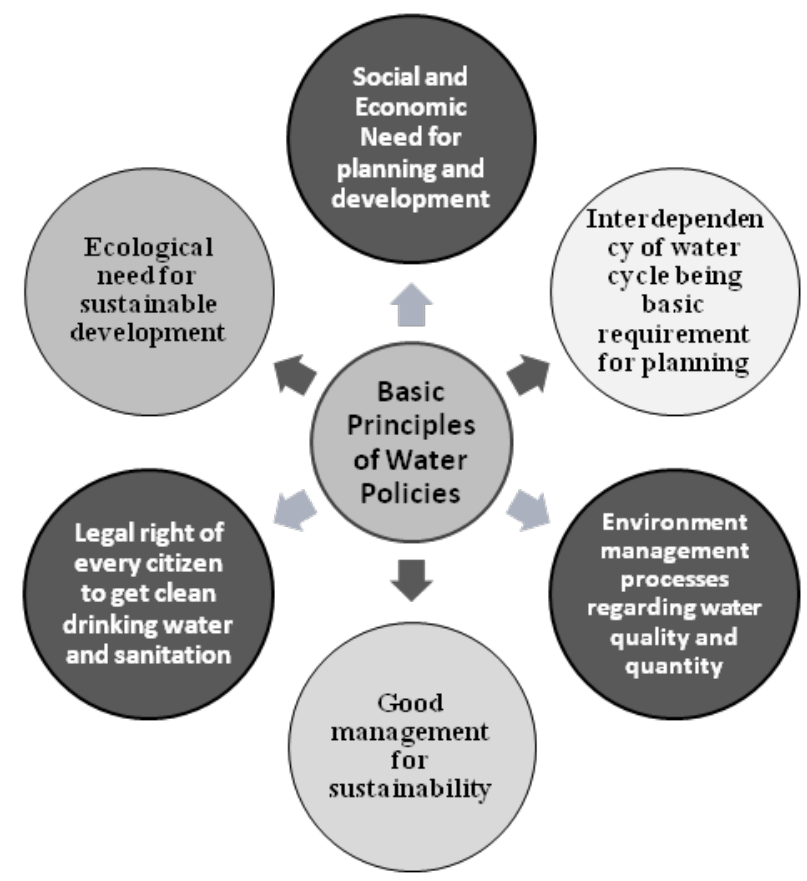

Fig 3. Basic principles of water policies in India (Source: Ministry of Water Resources, GoI ${ }^{(25)}$ )

\subsection{Chronological order of Water-related Policies in India and their key features [Table 2 ].}

Table 2. Chronological order of Water-related Policies in India and their key features

\begin{tabular}{|c|c|c|c|c|c|}
\hline Sr. No. & Policy Title & Authority & Year & Main Points/ key components & Reference \\
\hline 1 & $\begin{array}{l}\text { National } \\
\text { Water } \\
\text { Policy } \\
1987\end{array}$ & $\begin{array}{l}\text { Ministry } \\
\text { of Water } \\
\text { Resources, } \\
\text { Govern- } \\
\text { ment of } \\
\text { India }\end{array}$ & 1987 & $\begin{array}{l}\text { - Optimized utilization of all water resources. } \bullet \text { Present and future } \\
\text { challenges of droughts and floods. } \bullet \text { Priority to maintain ecological } \\
\text { balance. }\end{array}$ & GOI, 1987 \\
\hline 2 & $\begin{array}{l}\text { National } \\
\text { Water } \\
\text { Policy } \\
2002\end{array}$ & $\begin{array}{l}\text { National } \\
\text { Water } \\
\text { Resources } \\
\text { Council, } \\
\text { MoWR }\end{array}$ & 2002 & $\begin{array}{l}\text { - Local initiatives to water conservation. } \bullet \text { Implementation of Water } \\
\text { Rights }\end{array}$ & GOI, 2002 \\
\hline 3 & $\begin{array}{l}\text { National } \\
\text { Action Plan } \\
\text { on Climate } \\
\text { Change - } \\
2008\end{array}$ & $\begin{array}{l}\text { Ministry } \\
\text { of Water } \\
\text { Resources, } \\
\text { Govern- } \\
\text { ment of } \\
\text { India }\end{array}$ & 2008 & $\begin{array}{l}- \text { Limiting wastage of water. } \bullet \text { Dynamic investments of stakeholders. } \\
\text { - Impact of climate change on water resources and identifying: } \bullet \\
\text { Draughts prone areas, } \bullet \text { Flood prone areas, } \bullet \text { Coastal regions } \bullet \\
\text { Deficient rainfall areas, } \bullet \text { Areas of overexploited groundwater } \bullet \text { Areas } \\
\text { of Water quality affected, } \bullet \text { Snow fed river basins }\end{array}$ & $\begin{array}{l}\text { MOWR, } \\
2008\end{array}$ \\
\hline
\end{tabular}




\begin{tabular}{|c|c|c|c|c|c|}
\hline \multicolumn{6}{|c|}{ Table 2 continued } \\
\hline 4 & $\begin{array}{l}\text { National } \\
\text { Water } \\
\text { Policy } \\
2011\end{array}$ & $\begin{array}{l}\text { National } \\
\text { Water } \\
\text { Academy, } \\
\text { Pune, } \\
\text { Ministry } \\
\text { of Water } \\
\text { Resources, } \\
\text { Govern- } \\
\text { ment of } \\
\text { India }\end{array}$ & 2011 & $\begin{array}{l}\bullet \text { Ensuring safe \& adequate drinking water for all } \bullet \text { Encouraging water } \\
\text { conservation through small dams \& check dams etc. } \bullet \text { Promoting } \\
\text { recycling and reusing of water. } \bullet \text { Banning contamination of water } \\
\text { bodies. } \bullet \text { Ensuring measured volumetric supply. } \bullet \text { Restriction of tube } \\
\text { wells in overexploited groundwater zones. } \bullet \text { Providing concessional } \\
\text { loans for promoting water tanks \& revive pits. } \bullet \text { Obligating rooftop } \\
\text { rainwater reaping practice. }\end{array}$ & $\begin{array}{l}\text { GOI } \\
\text { MOWR } \\
\text { Pune, } \\
2011\end{array}$ \\
\hline 5 & $\begin{array}{l}\text { India } \\
\text { Infrastruc- } \\
\text { ture Report } \\
-2011\end{array}$ & $\begin{array}{l}\text { Mihir } \\
\text { Shah } \\
\text { committee }\end{array}$ & 2011 & $\begin{array}{l}\bullet \text { Collective efforts by the varsity, NGOs, think tanks, private \& Govt. } \\
\text { organizations. } \bullet \text { Focus on water rights, biological equity \& water } \\
\text { demands. } \bullet \text { Accentuation on water asset \& watershed management. } \bullet \\
\text { Coordination among foundations, planners \& sanitation administra- } \\
\text { tions. } \bullet \text { Increasing population, rapid urbanization \& industrial growth } \\
\text { are key factors for water crises. }\end{array}$ & $\begin{array}{l}\text { IDFCL, } \\
2011\end{array}$ \\
\hline 6 & $\begin{array}{l}\text { National } \\
\text { Water } \\
\text { Policy } \\
2012\end{array}$ & $\begin{array}{l}\text { Ministry } \\
\text { of Water } \\
\text { Resources, } \\
\text { Govern- } \\
\text { ment of } \\
\text { India }\end{array}$ & 2012 & $\begin{array}{l}\bullet \text { Adjustment with climate change } \bullet \text { Upgrading water available for } \\
\text { use } \bullet \text { Request for administration \& water use capabilities } \bullet \text { Applying } \\
\text { charges for water use } \bullet \text { Protection of river lobby, water structures, and } \\
\text { foundations } \bullet \text { The administration of flood and drought } \bullet \text { Cross border } \\
\text { rivers treaties. } \bullet \text { Research and training needs } \bullet \text { Execution of national } \\
\text { water policy }\end{array}$ & GOI 2012 \\
\hline 7 & $\begin{array}{l}\text { Draft } \\
\text { National } \\
\text { Water } \\
\text { Frame } \\
\text { Work Bill, } \\
2016\end{array}$ & $\begin{array}{l}\text { Government } \\
\text { of India }\end{array}$ & 2016 & $\begin{array}{l}- \text { Water as a basic legacy and asset, held in public belief } \bullet \text { Continuing } \\
\text { water contingent ecosystems } \bullet \text { Utilization of water according to } \\
\text { land use } \bullet \text { Proper ministration before using wastewater } \bullet \text { Viable } \\
\text { groundwater control } \bullet \text { Safeguarding water quality } \bullet \text { Alleviating } \\
\text { droughts, floods, and their control } \bullet \text { Resolving all interstate river } \\
\text { discharge conflicts }\end{array}$ & GOI 2016 \\
\hline 8 & $\begin{array}{l}\text { Water Pol- } \\
\text { icy and } \\
\text { Action Plan } \\
\text { for India } \\
2020\end{array}$ & $\begin{array}{l}\text { Government } \\
\text { of India }\end{array}$ & 2020 & $\begin{array}{l}- \text { Information structure and water asset evaluation } \bullet \text { Requirement } \\
\text { regulation, saving and proficiency use of water in each sector } \bullet \\
\text { Maintaining environment and river livelihood and controlling its } \\
\text { pollution } \bullet \text { Implementation of drainage basins and micro-irrigation } \\
\text { practices. } \bullet \text { Reaping multiple hydropower projects } \bullet \text { Incorporating } \\
\text { water user partnerships } \bullet \text { Involving river basin organizations and } \\
\text { associations. }\end{array}$ & GOI 2020 \\
\hline
\end{tabular}

\subsection{Critical analysis on the water policy structure and issues}

In 1987 MoWR, Government of India ${ }^{(26)}$ gave $1^{\text {st }}$ policy regarding the optimum utilization of all water resources considering the present and future challenges of droughts and floods throughout the nation. According to this policy, water is significant for human and creature life, for keeping up with environmental equilibrium and monetary improvement in numerous sorts, thinking about its expanding shortage, the arranging, and the executives of this regular asset and its ideal, efficient and fair usage had turned into a question of most priority.

A re-examined approach had been embraced by the National Water Resources Council in April 2002 ${ }^{(27)}$. The changes in the water policy were made keeping in mind the water crisis and local initiatives in water conservation. Vyuas ${ }^{(28)}$ recommended for more efforts to be made from Government side to spread awareness regarding the effectual water use and conservation too. Sheth ${ }^{(29)}$ in his paper indicated the success of managing the water asset of the Bhuj city by collaborating the partners using the Integrated Urban Water Resource Management (IUWM) process. Strengthening these initiatives requires strong implementation of water rights to the network, revival of the conventional procedures in protection, water executive framework, and acknowledgment of water as a typical property asset.

In another policy at the national level GoI, MoWR, National Action Plan on Climate Change ${ }^{(30)}$, the fundamental objective of the "National Water Mission" was "preservation of water, limiting wastage and guaranteeing its progressively even-handed circulation both across and inside States through coordinated water assets improvement and the board".

Another policy came into existence in $2011^{(31)}$, at National Water Academy, the delegates of Panchayati Raj Institutions were called upon to communicate their perspectives on the National Water Policy. The key observations in this policy are National/State Water Policies ensuring safe and adequate drinking water for all Indian citizens; after drinking water, irrigation 
being the $2^{\text {nd }}$ priority; encouraging the water conservation through small dams, check dams, etc.; provision of adequate drainage, sanitation facility and scheme like Nirmal Gram Yojna; encouraging the recycle and reuse of water; making open mindfulness crusade for water protection, safeguarding and expansion; contamination to water bodies must not go on without serious consequences and polluters pay rule ought to be authorized carefully, giving legitimate fencing around water bodies; ensuring the metered volumetric supply of water and its full compliance; strict restrictions of tube wells in over-exploited groundwater blocksban over the high water-intensive crops like paddy, sugarcane etc., and encouraging sustainable cropping pattern.

According to the 10th India Infrastructure Report ${ }^{(32)}$, IDFC's leader yearly distribution, the "India Infrastructure Report (IIR) 2011" was an aggregate exertion of supporters associated with colleges, "NGOs, think tanks, private and government organizations", and another autonomous specialists united on one stage by Infrastructure Development Finance Company. It was concluded that a billion people around the world and $3 / 4$ of Indians are without access to clean drinking water and living in water-deficits/ water shortage is significant challenge nowadays. Unchecked development in the interest of water, huge varieties, imbalances in accessibility across areas, buyer gatherings, and the impacts of environmental change are largely prone to fuel clashes over water later on.

In National Water Policy ${ }^{(33)}$ intensifies its objective by considering the climate changes and upgrading or enhancing the usability of available water. Better administrations were implemented for water use capabilities. Minimal water charges were introduced for better controlling the water wastages. Protection of river water, water structures, and foundations were also the main concerns of this policy.

Draft National water framework bill ${ }^{(34)}$ this Act was called the National Water Framework Act, 2016. The point of this ACT was to furnish an overall national legitimate system with standards for insurance, preservation, guideline and the board of water as an essential and focused on the natural asset, under which enactment and official activity on the water at all degrees of administration, as likewise water-use and water-related activities by people and their affiliations, open and private foundations and bodies, corporate of different sorts, can occur, and for issues associated therewith and accidental thereto. Under "Right to Water for Life" with features such as the safe, clean, and sufficient quantity of water is the fundamental right of every citizen irrespective of their rank, belief, religion, network, class, sexual orientation, age, incapacity, financial status, land possession and spot of living arrangement for drinking and various household purposes; each drinking water providing office needed to conform to the manuals of the local Public Health and Environmental Engineering Organization, Bureau of Indian Standard's particulars or the guidelines received by the fitting government as altered or overhauled every once in a while; it is the state's duty regarding guaranteeing every individual's entitlement to safe water forever regardless of whether the water administration is given by any private office.

Water Policy and Action Plan for India- 2020 ${ }^{(35)}$ focused on individuals' interest at all stages, the most noteworthy need ought to be agreed to the preparation of the individuals who are to deal with the water assets at all levels. The preparation must sharpen all accomplices to the requests of a people's arranging way to deal with water asset improvement. Preparing ought to likewise guarantee the specialized strengthening of every single neighbourhood establishment, create and oversee water assets.

\section{Research Objective III}

\subsection{Issues, Challenges, and opportunities}

Issues and Challenges: Since 1987, various water policies came into existence and the scarcer water and conflicts are the main issues. Water resources in India are hassled with contention and battle at all levels between states, among water use, and inside irrigation command areas. On a national assertion, entire water necessity is depended upon to outperform the utilizable potential by 2050 . The water table is being depleted at a distressing rate. An evaluation (2004) showed $29 \%$ of groundwater curtail as in the semi-basic, basic, or overexploited classifications, with the situations swiftly breaking down. Simultaneously, deflected and polluted surface water compromises the strength of streams and individuals. Restrain power to control new turns of events and forces like, population growth, industrial growth, and climatic change. Unless a sound framework is symbolized and applied in resources allotments, the struggle will keep on evolving because of shortage and contention for utilization. Parween ${ }^{(36)}$ through his study found the except the state of Odisha, no other state has framed and implemented the water strategy in line with the NWP.

Insufficient services and frail administration organizations and approaches: Deftly extension continues being the supported response to lack, rather than an improved organization. A decades-long push to broaden the country's watered zone has left Irrigation Departments in numerous states focused primarily on the improvement of physical works. A similar spotlight on flexibly increase may be observed in the greater part of the state organizations liable for urban and rustic water gracefully and sanitation. Albeit remarkable progress was noticed on exploring the provincial networks of water supply gracefully during 
the previous decade, a few organizations are executing appropriately even though poor support, tainting, or consumption of water resources.

Opportunities: To improve execution, diminish water-related issues, strengthen the development, progressively exhaustive change is required in the accompanying regions. Wescoat ${ }^{(37)}$ in his study made the districts and the blocks invigorate in drinking water strategy by using various techniques like village, blocks and district level surveys, interviews and GIS mapping etc. and finally focused over the potential improvements.

Between sectoral approaches at the basin level that incorporate surface water with groundwater, urban with provincial, amount with quality, and least streams and biological system administrations with waterway guideline for hydropower, flood board and deliberation for water gracefully and water system.

Decentralized and participatory assistance instruments, with a specific spotlight on improving administration approach, upgrading responsibility, straightforwardness, and stretching out the support of poor people.

One of the water resource management strategies is "Integrated Water Resources Management (IWRM)", which is a procedure that advances the organized turn of events and the executives of water, land, and related assets to augment financial, social and government assistance impartially without trading off the supportability of indispensable biological systems.

All throughout the planet, the water approach and the leaders are beginning to reflect from an overall perspective the interconnected idea of hydrological resources, and IWRM is creating as a recognized choice rather than the division by-region, hierarchical organization style that has ruled previously ${ }^{(38)}$.

Natural situation (Tropical Monsoon climate) causes enormous scope spatial and transient variety in water accessibility, repeating dry spells, and continuous floods in various parts of the country.

Climate change impact -Addressing the effect of environmental change on water accessibility and economy. Examination of situations for impacts on assets and use is needed to assess water arrangements.

\subsection{Guideline and recommendations:}

Through this paper, the author recommends that, while planning for the water infrastructure facilities for any city, region, state or zone the migrated people must also be taken into account along with the population forecasts. The governments must make arrangements for:

1. (a) Census of the migrants on a spot basis and updating of death and birth registrations.

(b) Crop proposals from the farmers may be taken into considerations for fulfilling crop water demands.

(c) Before setting up every Industry, their water demands and wastewater treatments and their reuse/disposal for horticulture purposes must be ensured.

(d) As per the current frameworks, the provision of all water demands is a state subjective, but many of the states are having very limited water resources and are dependents on the other states and hence there are different water issues between the states. So, the frameworks/organizations at the national level must take cognizance and resolve these water issues on an immediate basis.

(e) Many of the rivers flow up to their dangerous levels during rains and create flood risks, whereas on the other parts there are draughts situations. So, a broader planning/framework is needed to be implemented on each River Basin and ensures the meeting of all the water demands and conservation up to the maximum limit.

(f) Since most of the freshwater of many rivers becomes salty after joining the seas or oceans, hence the interlinking (however it needs a huge investment and will also have ecological effects) ${ }^{(39)}$ of rivers, creation of multipurpose hydro projects, conservation of water by construction dams, reservoirs, lakes, etc. is utmost and urgently required nowadays.

(g) The water utilized in the irrigation system area gives the effectiveness of 30-38\%, the water for drinking water supply and disinfection in the metropolitan region bears the misfortunes around 40-45\%. Villagers then again get exceptionally less measure of water so the stockpile should be adjusted.

To defeat the normal and human-caused difficulties like adverse impacts of environmental change, outrageous precipitation, water shortage during summers, drying up of streams, degrading water quality, and waterway contamination, planning of water resources is utmost necessary. Balamurgan ${ }^{(40)}$ discussed the impact of COVID-19 on the various domestic and commercial water supplies and the river water in India, He also recommended measures for improvement and management of water asset while facing future contagions.

Reform for institutional framework: Emphasize policies for one and all basis i.e. policies framed at national levels should be catering to the demands of each use and all levels either that may be states, districts, or river basins. 


\section{Conclusion}

As the population is growing exponentially and water is a key factor to support a growing population, moreover the migration of people in want of education, job, work or a proper earning from one place to another or from village to cities is very uncertain and uncontrolled too. All this is leading to great stress over the existing infrastructures/ framework of water resources in the migrated place and hence in turn the policy structure failure takes place. It is also necessary for maintaining ecological balance as sustaining an ecosystem depends on water. The review discusses policies framed at the International and National levels. From the above study, we conclude that the imbalance is due to poor management of the water from various levels of states, industries, surface runoff, lack of floodwater management, lack of dams, lakes, river basins, and many more. The focus should be on river water management and building dams for water conservation. The government should frame more policies that can be strictly followed by the industries and other wastewater management agencies. The water from a flood may be channelized with a proper plan through various sub-channels like irrigation channels etc. The wastewater from different sources should be treated and can be reused in agricultural or other commercial activities. If we have to make our future secure, we have to preserve water as it is an important candidate in various industries also.

This paper specifically concludes that:

1. (a) Rising water demand by escalating population invented for the water policies in India,

(b) Strengthening institutional arrangements and integrated planning is a better way of sustainable water asses than conventional planning, and

(c) Conservation and utilization of wastewater is also a good tool of water management.

\section{References}

1) Shyam AK. Water for future | India Water Portal [Internet]. India Water Portal. 2021. Available from: https://www.indiawaterportal.org/articles/waterfuture- 0 .

2) Étienne Lévesque, Anctil F, Van Griensven A, Beauchamp N. Evaluation of streamflow simulation by SWAT model for two small watersheds under snowmelt and rainfall. Hydrological Sciences Journal. 2008;53(5):961-976. doi:10.1623/hysj.53.5.961.

3) Francés GE, Quevauviller P, González ESM, Amelin EV. Climate change policy and water resources in the EU and Spain. A closer look into the Water Framework Directive. Environmental Science \& Policy. 2017;69:1-12. Available from: https://dx.doi.org/10.1016/j.envsci.2016.12.006.

4) Rouillard JJ, Benson D, Gain AK. Evaluating IWRM implementation success: are water policies in Bangladesh enhancing adaptive capacity to climate change impacts? International Journal of Water Resources Development. 2014;30(3):515-527. doi:10.1080/07900627.2014.910756.

5) Kampragou E, Apostolaki S, Manoli E, Froebrich J, Assimacopoulos D. Towards the harmonization of water-related policies for managing drought risks across the EU. Environmental Science \& Policy. 2011;14(7):815-824. doi:10.1016/j.envsci.2011.04.001.

6) Wada Y, van Beek LPH, Wanders N, Bierkens MFP. Human water consumption intensifies hydrological drought worldwide. Environmental Research Letters. 2013;8(3):034036-034036. Available from: https://dx.doi.org/10.1088/1748-9326/8/3/034036.

7) Brown CM, Lund JR, Cai X, Reed PM, Zagona EA, Ostfeld A, et al. The future of water resources systems analysis: Toward a scientific framework for sustainable water management. Water Resources Research. 2015;51(8):6110-6124. doi:10.1002/2015wr017114.

8) Walmsley N, Pearce G. Towards sustainable water resources management: bringing the Strategic Approach up-to-date. Irrigation and Drainage Systems. 2010;24(3-4):191-203. doi:10.1007/s10795-010-9100-z.

9) Tingey-Holyoak JL, Pisaniello JD, Burritt RL, Spassis A. Incorporating on-farm water storage safety into catchment policy frameworks: International best practice policy for private dam safety accountability and assurance. Land Use Policy. 2013;33:61-70. doi:10.1016/j.landusepol.2012.12.011.

10) Shen H, Huang S. China’s policies and practice on combatting IUU in distant water fisheries. Elsevier BV. 2021. Available from: https://dx.doi.org/10. 1016/j.aaf.2020.03.002. doi:10.1016/j.aaf.2020.03.002.

11) Iyer RR. National water policy: An alternative draft for consideration. Economic and Political Weekly. 2011;46:201-214.

12) Pol T. Water Policy leaves a lot to be desired [Internet]. 2012 [cited 2021 Jul 22]. 2012. Available from: https://www.dnaindia.com/analysis/commentwater-policy-leaves-a-lot-to-be-desired-1655972.

13) Singh KM, Meena MS, Kumar A, Personal M, R A. A Review of Indian Water Policy. 2013;45230:20-20. Available from: https://mpra.ub.uni-muenchen. de/id/eprint/45230.

14) Kathpalia GN, Kapoor R. Management of land and other resources for inclusive growth: India 2050. Water Energy International. 2015;66(4):24-40.

15) Kumar MD. A Critique of Mihir Shah Committee (2016) Report on Water Reforms in India. In: Water Policy Science and Politics [Internet]. Elsevier. 2018. Available from: https://linkinghub.elsevier.com/retrieve/pii/B9780128149034000051.

16) Water Scarcity Clock [Internet]. [cited 2021 Jun 5]. . Available from: https://worldwater.io/.

17) india_s_water_wealth - [Internet]. India WRIS Wiki. [cited 2021 Jun 5]. . Available from: https://indiawris.gov.in/wiki/doku.php?id=india_s_water_ wealth\&rev $=1575436012 \&$ vecdo=cite.

18) Chowdhury K, Behera B. Institutional dynamics and water resource management: the case of traditional water bodies in West Bengal. International Journal of Water Resource Development. 2021;p. 1-25. doi:10.1080/07900627.2021.1916448.

19) Sinisi L, Aertgeerts R. 2021. Available from: www.euro.who.int.

20) Saleth RM, Dinar A. Water institutional reforms: theory and practice. IWA Publishing. 2005. Available from: https://dx.doi.org/10.2166/wp.2005.0001. doi:10.2166/wp.2005.0001.

21) Kathpalia GN, Kapoor R. Institutional Structural Changes in the Water Sector. 2001.

22) Suresh S. Intersectoral Competition for Water Between Users and Uses in Tamil Nadu-India. Front Earth Sci. 2021;9:1-13. 
23) Mukherji A. Sustainable Groundwater Management in India Needs a Water-Energy-Food Nexus Approach. Appl Econ Perspect Policy. 2020;00(00). doi:10.1002/aepp.13123.

24) Rema N. The myth of India’s population explosion [Internet]. Times of India. 2016 [cited 2020 Jun 7]. 2016. Available from: https://timesofindia.indiatimes. com/blogs/staying-alive/the-myth-of-indias-population-explosion/.

25) Goi. GOI MOWR Pune. Summary record of discussions in the consultation meeting with representatives of Panchayati raj institutions on review of national water policy held on 2nd november, 2011 at National water academy, Pune [Internet]. 2011 [cited 2020 Apr 18].. 2012. Available from: http://jalshakti-dowr.gov.in/sites/default/files/NWP2012Eng6495132651_1.pdf.

26) MoWR. National Water Policy - 1987. Govt of India. 1987. .

27) Banerjee R. National Nutrition Policy. DK Taneja’s Health Policies and Programmes in India. 2017;46:21-21. doi:10.5005/jp/books/13071_4.

28) Nath J, The S. The Role of Government and the Public in Water Resource Management in India. Pollut Water Manag Resour Strateg Scarcity. 2021;16:339415.

29) Sheth D, Iyer M. Local water resource management through stakeholder participation: case study, arid region, India. IWA Publishing. 2021. Available from: https://dx.doi.org/10.2166/wpt.2021.025. doi:10.2166/wpt.2021.025.

30) Ministry Of Water Resources, National Water Mission under National Action Plan on Climate Change, Comprehensive mission document comprehensive mission document Volume-II. Ministry of Water Resources D GoI. 2008.

31) Pune GM. Summary record of discussions in the consultation meeting with representatives of Panchayati raj institutions on review of national water policy held on 2nd november, 2011 at National water academy. 2020. Available from: http://jalshakti-dowr.gov.in/sites/default/files/nwp201112157563970896_ 1.pdf.

32) Shah M, Dr. 2011. Available from: http://www.idfc.com/media_room/press_releases30.htm.

33) GOI M. Government of India Ministry of Water Resources. 2012. 2012.

34) Draft National water frame work bill. 2016.

35) India PC, Of. India PC of. Planning Commission (Government of India) [Internet]. 2020 [cited 2020 Apr 18]. . Available from: https://www. indiawaterportal.org/author/planning-commission-government-india.

36) Parween F, Kumari P, Singh A. Irrigation water pricing policies and water resources management. IWA Publishing. 2021. Available from: https: //dx.doi.org/10.2166/wp.2020.147. doi:10.2166/wp.2020.147.

37) Jr JLW, Murty JVR. District Drinking Water Planning for Sustainability in Maharashtra: Between Local and Global Scales. MDPI AG. 2021. Available from: https://dx.doi.org/10.3390/su13158288. doi:10.3390/su13158288.

38) Annual, Water C, Commission. 2019. Available from: http://cwc.gov.in/sites/default/files/arcwc2019-20.pdf.

39) Jeet P, Kumar A, Sundaram PK. Interlinking of River: Issues and Challenges. Hydrology [Internet]. 2020 Oct 12 [cited 2021 Dec 21 ]. .

40) Balamurugan M, Kasiviswanathan KS, Ilampooranan I, Soundharajan BS. COVID-19 Lockdown Disruptions on Water Resources, Wastewater, and Agriculture in India. Frontiers Media SA. 2021. Available from: https://dx.doi.org/10.3389/frwa.2021.603531. doi:10.3389/frwa.2021.603531. 